\title{
ANALISIS PENGARUH DIKLAT AUDIT INVESTIGATIF TERHADAP PENINGKATAN KOMPETENSI AUDITOR PEMERINTAH PUSAT DAN DAERAH PADA PUSDIKLATWAS BPKP CIAWI- BOGOR
}

\author{
Budiman Slamet \\ Fakultas Ekonomi Universitas Pakuan Bogor \\ Email : budiman.sl1954@gmail.com
}

\begin{abstract}
The role of human resources is very important and major in an organization followed by adjustments to the progress of science and technology, where HR is required to have increased competence. HR is needed who can carry out their duties to achieve organizational goals. Needed directed and planned efforts in the development of human resources, by conducting training (training), education programs in accordance with work programs. There are two types of training programs conducted by the BPKP Training Center, namely the JFA Certification Office (Auditor Functional Position) and the Substantive Technical Training (for example: Investigative Audit Training). The Investigative Audit Training conducted by the BPKP Pusdiklatwas can be carried out independently $(P N B P)$ in the sense of being borne by the Agency sending the participants, or fully borne by the BPKP Pusdiklatwas. This study aims to determine the training participants 'perceptions as well as direct training participants' supervisors on the implementation of investigative audit training and analyze their effects on improving the competence of training participants. Indicators of Education and Training are Conformity with Assignments, Teaching Methods, Lecturers / Instructors, Classroom Facilities, and Training Materials. While competency indicators are Knowledge, Skills, Collaboration, Motivation and Responsibility. The type of data collected in this study consists of primary and secondary data. Data analysis and techniques were performed with regression analysis using SPSS 17.0 software. This study argues that organizing an investigative audit training helps auditors in carrying out the technical implementation of an investigative audit in accordance with the work program of each Central / Regional Inspectorate, as well as increasing competence and developing the profession as an auditor. Training participants 'perceptions as well as direct training participants' conclusions gave the conclusion that, the implementation of investigative training had a real effect on increasing the competence of the Ministry / Institution / Regional Inspectorate auditors.
\end{abstract}

Keywords: Investigative Audit Training; Competency Enhancement Auditor

\begin{abstract}
Abstrak
Peran dari sumber daya manusia sangat penting dan utama dalam suatu organisasi diikuti penyesuaian kemajuan ilmu pengetahuan dan teknologi, dimana SDM dituntut memiliki peningkatan kompetensi. Perlu upaya yang terarah dan terencana dalam pengembangan SDM, dengan melakukan pelatihan (diklat), program pendidikan sesuai dengan program kerja.
\end{abstract}


Jurnal Ilmiah Akuntansi Universitas Pamulang - Vol. 7, No. 2, Juli 2019 - Marito \& Prasetya

Program diklat yang diselenggarakan Pusdiklatwas BPKP ada dua macam yaitu Diklat Sertifikasi JFA (Jabatan Fungsional Auditor) dan Diklat Teknis Substantif (misalnya: Diklat Audit Investigatif). Diklat Audit Investigatif yang diselenggarakan oleh Pusdiklatwas BPKP dapat dilakukan secara mandiri (PNBP) dalam arti ditanggung oleh Instansi yang mengirimkan peserta, maupun sepenuhnya ditanggung oleh Pusdiklatwas BPKP. Penelitian ini bertujuan untuk mengetahui persepsi peserta diklat maupun atasan langsung peserta diklat terhadap pelaksanaan diklat audit investigatif dan menganalisis pengaruhnya terhadap peningkatan kompetensi peserta diklat. Indikator Pendidikan dan Pelatihan adalah Kesesuaian Dengan Tugas, Metode Pengajaran, Widyaiswara/Instruktur, Fasilitas Ruang Kelas, dan Materi diklat. Sedangkan indikator kompetensi adalah Pengetahuan, Keterampilan, Kerjasama, Motivasi serta Tanggungjawab. Jenis data yang dikumpulkan dalam penelitian terdiri dari data primer maupun data sekunder. Teknik dan analisis data dilakukan dengan analisis regresi dengan menggunakan software SPSS 17.0. Penelitian ini mengemukakan bahwa penyelenggarakan diklat audit investigatif membantu auditor dalam menjalankan teknis pelaksanaan audit investigatif sesuai dengan program kerja masing-masing Inspektorat Pusat / Daerah, serta meningkatkan kompetensi dan mengembangkan profesi sebagai auditor. Persepsi peserta diklat maupun atasan langsung peserta diklat memberikan kesimpulan bahwa, penyelenggaraan diklat investigatif memberikan pengaruh nyata terhadap peningkatan kompetensi auditor Inspektorat Kementerian/Lembaga/Daerah.

Kata Kunci : Diklat Audit Investigatif; Peningkatan Kompetensi Auditor

\section{PENDAHULUAN}

Menteri Pendayagunaan Aparatur Negara dan Reformasi Birokrasi, mengatakan bahwa dari 4,7 juta Pegawai Negeri Sipil (PNS), sebanyak 95\% PNS tidak kompeten, dan hanya 5\% memiliki kompetensi dalam pekerjaannya (Harian Umum Pikiran Rakyat, Kamis 1 Maret 2012). Pegawai terutama PNS dalam melaksanakan pelayanan kepada masyarakat atau publik harus memiliki kompetensi dan mampu memberikan pelayanan yang baik dan juga memuaskan. Dari data yang disampaikan presentase dari jumlah PNS yang tidak kompeten sangatlah tinggi dan bisa memberikan opini yang negatif dari masyakarat.

Pernyataan Menteri Pendayagunaan Aparatur Negara dan Reformasi Birokrasi bisa dijadikan bahan untuk intropeksi diri bagi kalangan PNS untuk meningkatkan dan memperbaiki kompetensinya, karena PNS merupakan aparatur negara yang memiliki tugas memberikan pelayanan secara profesional, jujur, adil, dan merata kepada masyakarakat.

Program pendidikan dan pelatihan yang dilakukan oleh Pusdiklatwas BPKP bertujuan untuk meningkatkan kognitif (pengetahuan), psikomotorik (ketrampilan) serta behavioral/ attitude (perilaku) para auditor maupun calon auditor di lingkungan pemerintah maupun pemerintah daerah dalam rangka

* Corresponding author's e-mail: ekhatyo11@gmail.com

http://openjournal.unpam.ac.id/index.php/JIA 
Jurnal Ilmiah Akuntansi Universitas Pamulang - Vol. 7, No. 2, Juli 2019 - Marito \& Prasetya

pelaksanaan tugas dan tanggungjawabnya. Peserta dalam kegiatan pendidikan dan pelatihan baik pola mandiri/PNBP maupun pola yang sepenuhnya ditanggung BPKP adalah para auditor atau calon auditor yang telah mendapatkan usul mengikuti diklat dari masing-masing instansinya.

Pusdiklatwas BPKP melaksanakan diklat agar para auditor di lingkungan pemerintah Pusat/Daerah tidak stagnan dengan kompetensi yang telah dimiliki dan harus lebih berkembang mengikuti perkembangan situasi. Para auditor lingkungan pemerintah Pusat/Daerah yang tidak mengikuti DIKLAT kemungkinan akan dimutasi atau pembebasan sementara dan pemberhentian dari jabatan fungsional auditor.

Berdasarkan uraian sebelumnya, maka dapat dirumuskan permasalahan sebagai berikut:

1. Bagaimana persepsi peserta diktlat (auditor) mengenai pelaksanaan Diklat Audit Investigatif pada Pusdiklatwas BPKP?

2. Apakah ada pengaruh positif antara pelaksanaan Diklat Audit Investigatif terhadap Peningkatan Kompetensi Auditor?

Adapun tujuan yang ingin dicapai dalam penelitian ini adalah:

1. Mengetahui Persepsi Auditor pemerintah Pusat dan Daerah mengenai pelaksanaan Diklat Audit Investigatif pada Pusdiklatwas BPKP.

2. Menganalisis pengaruh Diklat terhadap peningkatan Kompetensi Auditor di lingkungan Pemerintah Pusat dan Daerah.

\section{KERANGKA TEORITIS DAN PENGEMBANGAN HIPOTESIS}

Dalam suatu institusi atau organisasi, pendidikan dan pelatihan biasanya disatukan menjadi diklat. Sedangkan Pusdiklat ( Pusat Pendidikan dan Pelatihan) adalah organisasi atau unit kerja yang mengelola pendidikan dan pelatihan pegawai. Menurut Edwin B.Flippo dalam Hasibuan ( 2006:69) Education is concerned with increasing general knowledge and understanding of our total environment. Training is the act of increasing the knowledge and skill of an employee for doing a particular job.

Pendidikan berhubungan dengan pemahaman dan peningkatan pengetahuan umu atas lingkungan kita secara menyeluruh. Sedangkan pelatihan adalah suatu usaha peningkatan keahlian dan pengetahuan seorang karyawan untuk mengerjakan pekerjaannya menjadi lebih baik. Dalam UU No. 2 Tahun 1989 disebut bahwa: "Pendidikan adalah usaha secara sadar untuk menyiapkan peserta didik melalui kegiatan bimbingan, pengajaran, dan atau latihan-latihan bagi peranannya di masa yang akan datang”. Menurut Dessler (1997), pelatihan adalah proses mengajarkan ketrampilan dasar yang dibutuhkan karyawan untuk menjalankan pekerjaannya. Pelatihan fokus pada ketrampilan yang dibutuhkan karyawan dalam menjalankan pekerjaannya dan untuk mengembangkan ketrampilannya yang bersifat jangka panjang. Pelatihan dibutuhkan untuk tugas di masa depan dan memecahkan permasalahan organisasi juga membantu manajemen dalam jangka panjang

Proses belajar untuk mengajarkan suatu pengetahuan dan ketrampilan baru

* Corresponding author's e-mail: ekhatyo11@gmail.com

http://openjournal.unpam.ac.id/index.php/JIA 
Jurnal Ilmiah Akuntansi Universitas Pamulang - Vol. 7, No. 2, Juli 2019 - Marito \& Prasetya

kepada orang lain disebut sebagai proses pembelajaran. Dalam melatih karyawan, dibutuhkan pengetahuan mengenai bagaimana cara orang belajar. Saran yang didasarkan pada teori belajar adalah:

1. Pada awal pelatihan, diberikan pandangan mengenai materi yang akan disajikan karena lebih mudah bagi para peserta pelatihan untuk memahami dan mengingat bahan penting. Bantuan visual diberikan untuk memudahkan proses pembelajaran sekaligus menggunakan konsep dan istilah yang sudah umum di ketahui oleh para peserta

2. Memaksimalkan keserupaan situasi pelatihan dan tempat kerja dan memberikan praktik pelatihan akan memudahkan mentransfer pengetahuan, ketrampilan dan perilaku dari tempat pelatihan ke tempat kerja.

3. Para peserta diberikan motivasi, praktik realistik dan peserta diberikan kebebasan dalam menentukan caranya sendiri dalam belajar sehingga akan lebih efektif (Dessler,1997).

Indikator Pendidikan dan Pelatihan adalah Materi yang Diajarkan, Metode yang Digunakan, Sarana Fasilitas Pendukung, Kemampuan Widyaiswara/ Instuktur, dan Kemampuan Peserta Diklat. Pelaksanaan Diklat Audit Investigatif terhadap peningkatan kompetensi auditor dilakukan dengan melihat persepsi Atasan Langsung peserta diklat dalam pengisian kuesioner. Setelah pengisian kuesioner akan dilihat bagaimana diklat yang telah dilaksanakan mempengaruhi peningkatan kompetensi auditor melalui alat analisis regresi.

Kemampuan (capability) memiliki pengertian yang sama dengan kompetensi. Seseorang yang memiliki kemampuan, pengetahuan dan keahlian melakukan sesuatu secara efisien dan efektif akan disebut memiliki kompetensi

Berdasarkan Peraturan Pemerintah Nomor 101 Tahun 2000 tentang Diklat Jabatan PNS, bahwa kompetensi adalah kemampuan dan karakteristik yang dimiliki oleh seorang PNS berupa pengetahuan, keterampilan dan sikap perilaku yang diperlukan dalam melaksanakan tugas jabatannya.

Kemampuan seseorang dalam melaksanakan pekerjaanya dengan memenuhi standar, menjalankan tugas dengan sempurna dan merujuk pada kecakapan atau kelayakan seseorang dalam sebuah organisasi disebut dengan kompetensi. Kompetensi berhubungan dengan prestasi kerja dan berdasarkan kepada motif, sifat, sikap atau nilai, tahap pengetahuan atau pemikiran (kognitif) atau kemahiran seseorang dalam bertingkah laku

Dengan demikian, kompetensi menunjukkan keterampilan dan pengetahuan yang dicirikan oleh profesionalisme dalam suatu bidang tertentu (misalnya: Auditor) sebagai sesuatu yang terpenting atau sebagai unggulan bidang tersebut.

Kompetensi pegawai terdiri dari pengetahuan (knowledge), kemampuan/keterampilan (skill), sikap (attitude) disesuaikan dengan bidang pekerjaan yang dibutuhkan oleh organisasi (misalnya: Aparat Pengawasan Intern Pemerintah/APIP), sehingga dapat menghasilkan kinerja pegawai yang berprestasi.

Kompetensi menurut Kode Etik-Asosiasi Auditor Intern Pemerintah Indonesia (KE-AAIPI) adalah kemampuan dan karakteristik yang dimiliki oleh seseorang, berupa pengetahuan, ketrampilan, dan sikap perilaku yang diperlukan dalam pelaksanaan tugas jabatannya. Auditor intern pemerintah menerapkan 
Jurnal Ilmiah Akuntansi Universitas Pamulang - Vol. 7, No. 2, Juli 2019 - Marito \& Prasetya

Pengetahuan, Keahlian dan Keterampilan, serta pengalaman yang diperlukan dalam pelaksanaan layanan pengawasan intern.

Sedangkan Aturan Perilaku KE-AAIPI yang terkait dengan Kompetensi, antara lain:

a. Pengalaman yang diperlukan dalam memberikan layanan disesuaikan dengan pengetahuan, keahlian dan ketrampilan.

b. Melakukan pengawasan sesuai dengan Standar Audit Intern Pemerintah Indonesia; dan

c. Meningkatkan keahlian secara terus menerus secara efektif dan menjaga kualitas pelaksanaan tugasnya yang diperoleh dari pelatihan, pendidikan formal, sertifikasi ataupun pengalaman kerja

Indikator Kompetensi adalah Pengetahuan, Keterampilan, Kerjasama, Motivasi serta Tanggung jawab. Pengaruh Diklat Audit Investigatif terhadap kompetensi auditor dilakukan dengan melihat persepsi peserta diklat (auditor) dalam pengisian kuesioner. Setelah pengisian kuesioner akan dilihat bagaimana diklat yang telah dilaksanakan mempengaruhi peningkatan kompetensi auditor melalui alat analisis regresi.

Setiawan (2006) dalam penelitiannya yang berjudul Analisis Program Pelatihan dan Pengaruhnya terhadap Kinerja Karyawan (Studi Kasus PT.Mitra Infoparama), berdasarkan hasil analisis deskriptif bahwa proses program pelatihan yang dilakukan PT.Mitra Infoparama sudah cukup baik. Hubungan yang terjadi antara program pelatihan dengan kinerja karyawan cukup kuat.

Amelia (2007) dalam penelitiannya yang berjudul Analisis Pengaruh Pendidikan dan Pelatihan Internal terhadap Pembelajaran Pegawai (Studi Kasus BAKOSURTANAL Cibinong-Bogor) mengemukakan bahwa dengan adanya diklat internal sangat berpengaruh nyata dalam pembelajaran pegawai.

Elfina Marlia (2007) dalam penelitiannya yang berjudul Pengaruh Program Pendidikan dan Pelatihan Terhadap Prestasi Kerja Karyawan pada PT Inti (Persero) Bandung, mengemukakan bahwa pendidikan dan pelatihan yang diselenggarakan PT Inti (Persero) Bandung berpengaruh positif terhadap prestasi kerja karyawan, dan mempunyai hubungan yang kuat antara kedua variabel tersebut.

Tetty Liani Sembiring (2012) dalam penelitiannya yang berjudul Pengaruh Pendidikan dan Pelatihan Terhadap Peningkatan Kinerja Karyawan PT Perkebunan Nusantara III (Persero) Medan, mengemukakan bahwa pendidikan dan pelatihan mempunyai pengaruh positif dan signifikan terhadap kinerja pegawai.

Riza Resita (2013) dalam penelitiannya yang berjudul Pengaruh Pendidikan dan Pelatihan (Diklat) Terhadap Kinerja Pegawai pada Badan Perpustakaan dan Arsip Daerah Daerah Istimewa Yogyakarta (BPAD-DIY), mengemukakan bahwa pendidikan dan pelatihan mempunyai pengaruh positif dan signifikan terhadap kinerja pegawai. 
Jurnal Ilmiah Akuntansi Universitas Pamulang - Vol. 7, No. 2, Juli 2019 - Marito \& Prasetya

Kerangka pemikiran dari penelitian ini dapat dilihat sebagai berikut:

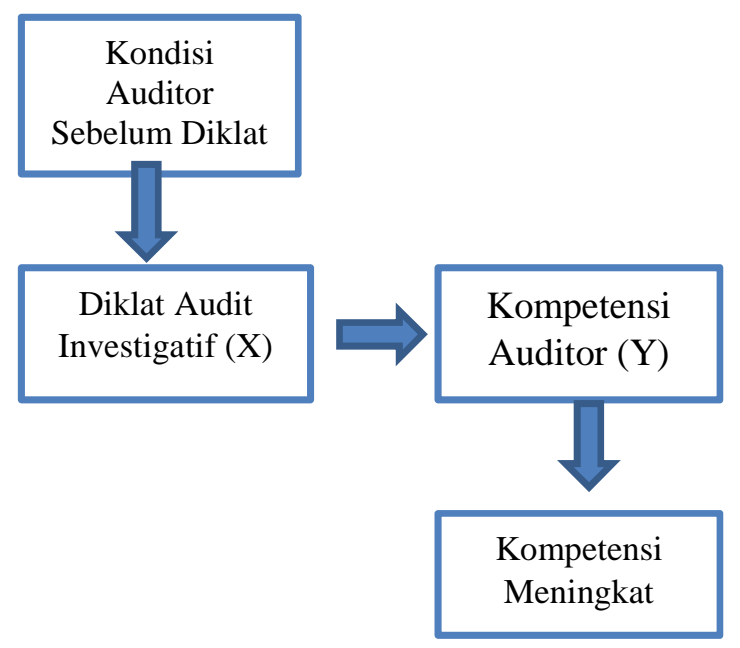

\section{Gambar 1: Kerangka Pemikiran}

Berdasarkan kerangka pemikiran tersebut di atas, dikembangkan hipotesis. Hipotesa dalam penelitian ini adalah " Diklat Audit Investigatif berpengaruh terhadap peningkatan kompetensi auditor pemerintah pusat/daerah". Kemudian untuk mengetahui antara variabel $\mathrm{X}$ dan $\mathrm{Y}$, maka dilakukan uji hipotesis nol, yaitu:

$\mathrm{H}_{\mathrm{o}}$ : Diklat Audit Investigatif tidak berpengaruh positif dan signifikan terhadap peningkatan Kompetensi Auditor Pemerintah Pusat/Daerah.

$\mathrm{H}_{\mathrm{a}}$ : Diklat Audit Investigatif berpengaruh positif dan signifikan terhadap peningkatan Kompetensi Auditor Pemerintah Pusat/Daerah.

\section{METODE RISET}

Penelitian ini menggunakan sampel data kuesioner yang diperoleh dari jawaban dari responden dalam hal ini, yaitu: peserta Diklat Audit Investigatif maupun Atasan Langsung peserta diklat tersebut. Populasi yang diteliti dalam penelitian ini adalah seluruh peserta Diklat Audit Investigatif yang di selenggarakan oleh Pusdiklatwas BPKP selama tahun 2017. Dengan asumsi tiap kelas ada 30 orang peserta, maka sesuai kalender diklat ( Kaldik) Teknis Subtansi Tahun 2017, ada sekitar 10 kelas atau sekitar 300 orang peserta diklat.

Pemilihan sampel dilakukan dengan menggunakan convenience sampling atau pengumpulan informasi dari anggota populasi yang dengan senang hati bersedia memberikannya. Jumlah sampel yang reprensentative dilakukan berdasarkan pada tingkat pengembalian kuisioner yang disebarkan kepada peserta diklat, disamping menggunakan rumus Slovin

$$
\mathbf{n}=\mathbf{N}:\left\{\mathbf{N} . \mathbf{d}^{2}+\mathbf{1}\right\}
$$

Artinya seandainya seluruh Diklat Audit Investigatif pemerintah Pusat dan Daerah diikuti oleh 300 peserta. Kemudian galat pendugaan (d) sebesar 5\%, maka sampel

* Corresponding author's e-mail: ekhatyol1@gmail.com

http://openjournal.unpam.ac.id/index.php/JIA 
Jurnal Ilmiah Akuntansi Universitas Pamulang - Vol. 7, No. 2, Juli 2019 - Marito \& Prasetya

yang dipakai untuk membuktikan hipotesis, cukup diwakili oleh sekitar 172 peserta/responden.

Berdasarkan hasil penelitian yang dilakukan jumlah Peserta diklat maupun Atasan Langsung peserta diklat, yang mengembalikan kuesioner adalah sebanyak 173 peserta/responden. Jumlah tersebut sudah melebihi sampel yang dapat diambil dari populasi yang dapat diperoleh pada galat $5 \%$.

Pengumpulan data dilakukan dengan metode kuesioner. Kuisioner yang disebarkan di isi dan dijawab oleh auditor peserta diklat investigatif maupun oleh atasan peserta diklat. Untuk mengukur pendapat responden terhadap variabel bebas/ independen, digunakan skala Likert yaitu: skala yang berisi 5 (lima) tingkat preferensi jawaban dengan pilihan sebagai berikut:

Angka 1 = Sangat Tidak Setuju atau Sangat Tidak Mengetahui (STS/STM)

Angka 2 = Tidak Setutu atau Tidak Mengetahui (TS/TM)

Angka 3 = Cukup Setuju atau Cukup Mengetahui (CS/CM)

Angka $4=$ Setuju atau Mengetahui (S/M)

Angka 5 = Sangat Setuju atau Sangat Mengetahui (SS/SM)

Adapun uji yang digunakan dalam penelitian ini adalah dengan menggunakan:

1. Uji Validitas, yaitu suatu ukuran yang menunjukkan tingkat keabsahan dan kevalidan suatu alat ukur atau instrument penelitian.

2. Uji Reliabilitas, indeks yang menunjukan sejauh mana suatu pengukuran tanpa bias (bebas kesalahan) dan karena itu menjamin pengukuran yang konsisten lintas waktu dan lintas beragam item dalam instrument (Sekaran, 2010).

3. Analisa regresi Linier, digunakan unutuk mengetahui besarnya pengaruh diklat audit investigatif terhadap peningkatan kompetensi peserta diklat.

4. Pengujian secara parsial (uji t), digunakan untuk menguji hipotesis secara parsial guna menunjukkan pengaruh variabel independen ( Diklat Audit Investigatif) terhadap variabel dependen (Kompetensi Auditor yang menjadi peserta diklat tersebut).

\section{ANALISIS DATA DAN PEMBAHASAN}

Penelitian ini mengambil 2 kelompok sampel yang berbeda yaitu: kelompok peserta diklat (para auditor dari Kementerian/Lembaga/Pemerintah Daerah), dimana kelompok ini diberi satu set kuesioner yang meminta tanggapan mereka atas pelaksanaan Diklat Audit Investigatif. Jumlah sampel adalah peserta diklat sebanyak 173 auditor. Kelompok sampel kedua adalah atasan langsung dari masing-masing auditor yang mengikuti Diklat Majerial Pengawasan. Atasan langsung sebanyak 32 orang sebagai sumber yang diberi kewenangan dalam menilai kinerja auditor. Identitas responden dijelaskan dalam tabel berikut : 
Jurnal Ilmiah Akuntansi Universitas Pamulang - Vol. 7, No. 2, Juli 2019 - Marito \& Prasetya

Tabel 1: Karakteristik identitas responden

\begin{tabular}{|c|c|c|c|c|}
\hline & \multicolumn{2}{|c|}{$\begin{array}{l}\text { Peserta diklat } \\
\text { (Auditor) }\end{array}$} & \multicolumn{2}{|c|}{$\begin{array}{c}\text { Atasan } \\
\text { Langsung } \\
\text { Auditor }\end{array}$} \\
\hline & Jumlah & $\%$ & Jumlah & $\%$ \\
\hline Jenis kelamin & & & & \\
\hline Laki-laki & 118 & 68.21 & 21 & 65.63 \\
\hline Perempuan & 55 & 31.79 & 11 & 34.38 \\
\hline \multicolumn{5}{|l|}{ Umur } \\
\hline$<30$ th & 4 & 2.31 & 1 & 3.13 \\
\hline $31-45$ th & 78 & 45.09 & 5 & 15.63 \\
\hline$>46$ th & 91 & 52.60 & 26 & 81.25 \\
\hline \multicolumn{5}{|l|}{ Pendidikan } \\
\hline D3 & 3 & 1.73 & - & - \\
\hline S1 / D4 & 116 & 67.05 & 18 & 56.25 \\
\hline $\mathrm{S} 2 / \mathrm{S} 3$ & 54 & 31.21 & 14 & 43.75 \\
\hline \multicolumn{5}{|l|}{ Lama bekerja } \\
\hline$<6$ th & 6 & 3.47 & - & - \\
\hline $6-10$ th & 55 & 31.79 & 4 & 12.50 \\
\hline$>11$ th & 112 & 64.74 & 28 & 87.50 \\
\hline
\end{tabular}

Berdasarkan jenis kelamin, auditor laki-laki menunjukkan memiliki jumlah yang lebih banyak dibanding auditor perempuan yaitu 68,21\% dibanding $31,79 \%$. Berdasarkan kelompok umur responden yang terbanyak adalah yang berumur lebih dari 46 tahun yaitu sebanyak 52,60\%. Berdasarkan tingkat pendidikan auditor BPKP didominasi oleh pendidikan S1/D4 yaitu sebanyak 67,05\%, sedangkan berdasarkan lama masa kerja, auditor Pemerintah Pusat dan Daerah sebagian besar memiliki masa kerja lebih dari 11 tahun yaitu sebanyak $64,74 \%$.

Untuk karakteristik atasan langsung responden auditor, berdasarkan jenis kelamin menunjukkan juga bahwa sebagian besar berjenis kelamin laki-laki $(65,63 \%)$, berdasarkan umur sebagian besar berumur lebih dari 46 tahun $(81,25 \%)$, berdasarkan pendidikan sebagian besar berpendidikan S1/D4 $(56,25 \%)$ dan berdasarkan masa kerja sebagian besar sudah bekerja selama lebih dari 11 tahun $(87,50 \%)$.

Tabel yang tersaji di bawah ini menggambarkan statistik deskriptif variabel Pendidikan Pelatihan (Diklat) sebagai variabel independen (bebas), dengan variabel Peningkatan Kompetensi Auditor sebagai variabel dependen (terikat).

Tabel 2: Deskripsi jawaban responden

\begin{tabular}{lccrrr}
\hline & $\mathrm{N}$ & $\begin{array}{c}\text { Mini } \\
\text { mum }\end{array}$ & Maximum & Mean & $\begin{array}{c}\text { Std. } \\
\text { Deviation }\end{array}$ \\
\hline $\begin{array}{l}\text { Pendidikan } \\
\text { dan Pelatihan }\end{array}$ & 173 & 3.130 & 5.000 & 4.129 & 0.367 \\
$\begin{array}{l}\text { Peningkatan } \\
\text { Kompetensi } \\
\text { Auditor }\end{array}$ & 173 & 3.000 & 5.000 & 4.198 & 0.423 \\
\hline
\end{tabular}

* Corresponding author's e-mail: ekhatyo11@gmail.com 
Jurnal Ilmiah Akuntansi Universitas Pamulang - Vol. 7, No. 2, Juli 2019 - Marito \& Prasetya

Berdasarkan penilaian atas intensitas pelaksanaan Pendidikan dan Pelatihan (Diklat) investigasi menunjukkan bahwa variabel pendidikan dan pelatihan investigasi rata-rata empiris berada di atas rata-rata teoritis. Hal ini ditunjukkan dengan diperolehnya rata-rata indeks skor sebesar 4,129. Kondisi demikian mencerminkan bahwa tingkat Diklat Investigasi yang diberikan kepada auditor di lingkungan Aparat Pengawasan Internal Pemerintah (APIP) Pusat dan Daerah. Nilai rata-rata sebesar 4,129 tersebut menunjukkan lebih besar dari nilai tengah skala ukuran 5 yaitu sebesar 3,0. Hal ini menunjukkan bahwa pendidikan dan pelatihan investigatif yang diberikan kepada auditor sudah dinilai dengan baik dan sesuai. Hal ini menunjukkan bahwa pendidikan dan pelatihan investigatif yang diberikan kepada auditor sudah dinilai dengan baik dan sesuai ketrampilan dasar yang dibutuhkan untuk menjalankan suatu pekerjaan.

Berdasarkan skor peningkatan kompetensi auditor yang diperoleh menunjukkan rata-rata skor sebesar 4,198. Kondisi demikian mencerminkan persepsi adanya peningkatan kompetensi para auditor APIP Pusat dan Daerah. Nilai rata-rata sebesar 4,198 tersebut menunjukkan lebih besar dari nilai tengah skala ukuran 5 yang digunakan. Hal ini menunjukkan bahwa auditor memiliki semakin memiliki kinerja yang lebih baik setelah pemberian pendidikan dan pelatihan.

\section{Uji Validitas dan Reliabilitas}

Pengujian validitas dilakukan dengan menggunakan nilai corrected item total correlation, sedangkan pengujian reliabilitas menggunakan rumus Croncabh Alpha.

Tabel 3: Hasil Pengujian Validitas

\begin{tabular}{|cllccc|}
\hline \multicolumn{1}{|c|}{$\begin{array}{c}\text { Variabel / } \\
\text { No }\end{array}$} & $\begin{array}{c}\text { Range } \\
\text { Indikator }\end{array}$ & r tabel & Keterangan & Alpha \\
\hline 1 & $\begin{array}{l}\text { Diklat } \\
\text { Investigasi } \\
\text { Indikator 1 s.d 23 }\end{array}$ & 0.349 s.d. 0.676 & 0.300 & Valid & 0,910 \\
& $\begin{array}{l}\text { Kompetensi } \\
\text { Auditor }\end{array}$ & & & & \\
2 & $\begin{array}{l}\text { Indikator 1 s.d. } \\
20\end{array}$ & 0.523 s.d. 0.709 & 0.300 & Valid & 0,937 \\
\hline
\end{tabular}

Hasil uji validitas menunjukkan, koefisien korelasi yang lebih besar dari 0,30 artinya bahwa semua indikator tersebut adalah valid.

Hasil uji reliabilitas menunjukkan bahwa kedua variabel mempunyai koefisien Alpha diatas 0,60 sehingga dapat dikatakan semua konsep pengukur masingmasing variabel dari kuesioner adalah reliabel yang berarti bahwa kuesioner yang digunakan dalam penelitian ini merupakan kuesioner yang handal.

\section{Uji Asumsi Klasik}

* Corresponding author's e-mail: ekhatyol1@gmail.com 
Jurnal Ilmiah Akuntansi Universitas Pamulang - Vol. 7, No. 2, Juli 2019 - Marito \& Prasetya

\section{Uji Normalitas}

Uji normalitas menggunakan Uji Kolmogorov Smirnov menunjukkan bahwa tingkat signifikansi sebesar 0,589 dan 0,081 dimana keduanya lebih besar dari 0,05 . Dengan demikian data dinyatakan normal dan telah memenuhi asumsi uji normalitas.

Tabel 4: Uji Normalitas

\begin{tabular}{|c|c|c|c|}
\hline & & $\begin{array}{c}\text { Pendidikan } \\
\text { dan Pelatihan }\end{array}$ & $\begin{array}{c}\text { Peningkatan } \\
\text { Kompetensi } \\
\text { Auditor }\end{array}$ \\
\hline \multicolumn{2}{|l|}{$\mathrm{N}$} & 173 & 173 \\
\hline \multirow{2}{*}{$\begin{array}{l}\text { Normal } \\
\text { Parameters }^{\mathrm{a}}\end{array}$} & Mean & 4.129 & 4.1980 \\
\hline & $\begin{array}{l}\text { Std. } \\
\text { Deviation }\end{array}$ & 0.3667 & .42304 \\
\hline \multirow{3}{*}{$\begin{array}{l}\text { Most } \\
\text { Extreme } \\
\text { Differences }\end{array}$} & Absolute & 0.059 & 0.096 \\
\hline & Positive & 0.055 & 0.096 \\
\hline & Negative & -0.059 & -0.067 \\
\hline \multicolumn{2}{|c|}{ Kolmogorov-Smirnov Z } & 0.773 & 1.266 \\
\hline \multicolumn{2}{|c|}{ Asymp. Sig. (2-tailed) } & 0.589 & 0.081 \\
\hline
\end{tabular}

\section{Uji Heteroskedastisitas}

Pengujian heteroskedastisitas dilakukan dengan menggunakan uji Glejser

Tabel 5: Uji Gangguan Heteroskedastsitas

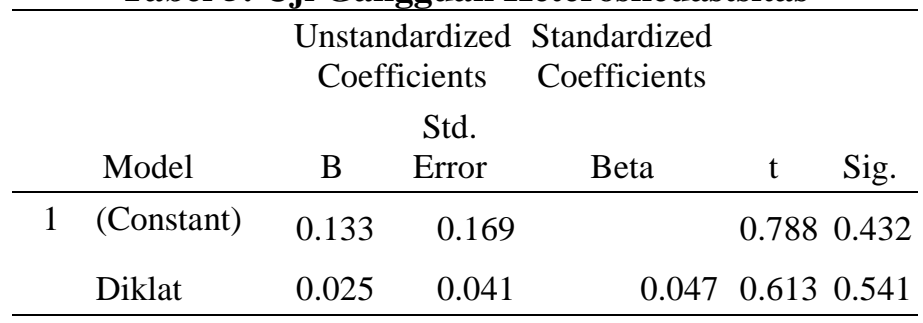

a. Dependent Variable: AbsRes

Dan uji heteroskedasitas dilakukan dengan grafik Scatterplot terlihat titiktitik yang menyebar secara acak, tidak membentuk suatu pola tertentu yang jelas, serta tersebar baik di atas maupun di bawah angka 0 (nol) pada sumbu Y. Hal ini berarti tidak terjadi heteroskedastisitas pada model regresi. 
Jurnal Ilmiah Akuntansi Universitas Pamulang - Vol. 7, No. 2, Juli 2019 - Marito \& Prasetya

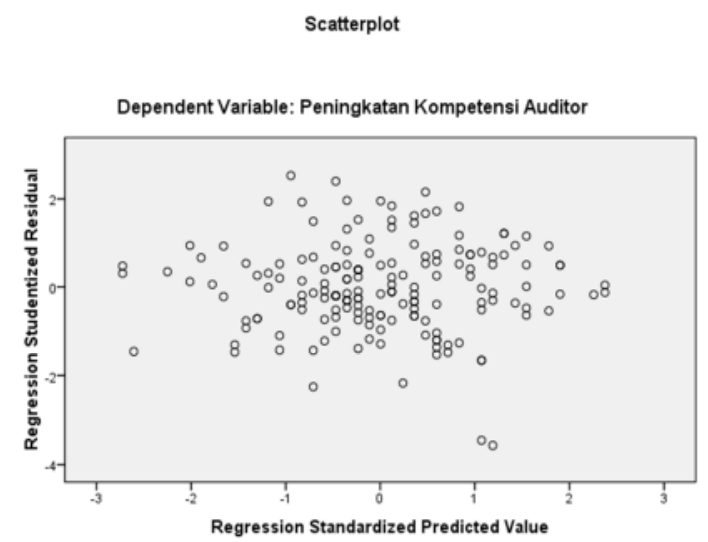

Gambar 2: Uji Heteroskedastisitas

\section{Analisa Regresi Linear}

Berdasarkan hasil penghitungan, maka persamaam regresi yang terbentuk pada uji regresi adalah:

$$
\mathbf{Y}=0,928+0,792 \mathrm{X}+\mathbf{e}
$$

Persamaan regresi tersebut menjelaskan bahwa koefisien regresi variabel pendidikan dan pelatihan (x) diperoleh sebesar 0,792 dengan arah positif. hal ini menunjukkan bahwa variabel pendidikan dan pelatihan mempunyai potensi untuk meningkatkan kompetensi auditor di lingkungan pemerintah pusat maupun daerah.

\section{Pengujian Hipotesis}

\section{Analisis Koefisien Determinasi}

Berdasarkan hasil pengujian koefisien determinasi pada Tabel di bawah ini, menunjukan bahwa koefisien determinasi (adjusted $R^{2}$ ) dapat diketahui bahwa koefisien sebesar 0,468. Hasil ini menunjukkan bahwa sebesar 46,8\% kompetensi para auditor yang ikut diklat di Pusdiklatwas BPKP dapat meningkat seiring dengan semakin baiknya pendidikan dan pelatihan investigasi yang diberikan, dan sisanya sebesar 53,2\% kompetensi auditor dapat dipengaruhi variabel lain.

\begin{tabular}{|c|c|c|c|c|}
\hline & Koef & $\begin{array}{r}\text { Std } \\
\text { Error }\end{array}$ & $\mathrm{t}$ & sig \\
\hline (Constant) & 0.928 & 0.266 & 3.488 & 0.001 \\
\hline Diklat & 0.792 & 0.064 & 12.345 & 0.000 \\
\hline $\begin{array}{l}R^{2} \\
\text { Adj } R^{2}\end{array}$ & $\begin{array}{l}0.471 \\
\mathbf{0 . 4 6 8}\end{array}$ & & & \\
\hline
\end{tabular}

Hasil pengujian diperoleh nilai $t$ hitung untuk variabel Pendidikan dan Pelatihan menunjukkan nilai $t$ hitung $=12,345$ dengan nilai signifikansi sebesar $0,000<0,05$. Dengan demikian diperoleh bahwa hipotesis yang menyatakan bahwa Pendidikan dan pelatihan memiliki pengaruh positif yang signifikan terhadap peningkatan kompetensi auditor dapat diterima. 
Jurnal Ilmiah Akuntansi Universitas Pamulang - Vol. 7, No. 2, Juli 2019 - Marito \& Prasetya

Berdasarkan hasil analisis statistik menunjukkan bahwa pendidikan dan pelatihan (diklat) khususnya dalam bidang investigatif memiliki hubungan fungsional dan memiliki pengaruh signifikan positif terhadap peningkatan kompetensi para auditor yang menjadi peserta diklat di Pusdiklatwas BPKP. Ini berarti bahwa makin tinggi atau makin banyak pendidikan dan pelatihan yang diikuti auditor maka akan semakin meningkat kompetensi auditor tersebut. Faktor dominan atau penentu utama terhadapat kompetensi auditor adalah pedidikan dan pelatihan, karena semakin banyak atau semakin baik pemberian pendidikan dan pelatihan kepada auditor, maka akan semakin meningkatkan kompetensi mereka. Hal ini menunjukkan pula bahwa pendidikan dan pelatihan (diklat) dapat digunakan untuk memprediksi perkembangan atau peningkatan kompetensi auditor. Koefisien regresi variabel pendidikan dan pelatihan diperoleh sebesar 0,792 yang menunjukkan akan adanyan potensi perolehan peningkatan kompetensi auditor jika auditor menerima pendidikan dan pelatihan investigasi yang lebih baik. Hal ini dapat memberikan implikasi bahwa model dan bentuk pendidikan dan pelatihan bagi auditor harus selalu ditingkatkan apabila keinginan untuk mendapatkan peningkatan yang signifikan pada kompetensi auditor di waktu yang akan datang.

Hasil deskripsi variabel menunjukkan bahwa rata-rata skor pendidikan dan pelatihan yang diperoleh auditor sudah dinilai baik di mana rata-rata skor pendidikan dan pelatihan adalah sebesar 4,129 pada skala 5. Hal ini berarti bahwa auditor sudah menilai bahwa bentuk diklat yang diberikan kepada mereka sudah dinilai secara positif dan sesuai dengan bidang kerja mereka. Hal ini didukung dengan kondisi bahwa materi diklat yang diberikan dapat menunjang pekerjaan. meningkatkan pengetahuan dalam pekerjaan. Kondisi tersebut dapat meningkatkan pemahaman mereka terhadap apa yang seharusnya mereka lakukan dalam pekerjaan mereka. Kondisi diklat yang baik juga didukung oleh instruktur yang berpengalaman serta metode pelatihan yang digunakan pada saat program diklat mudah untuk dimengerti. Kondisi tersebut nampaknya dapat meningkatkan motivasi auditor untuk bekerja dengan lebih baik.

\section{KESIMPULAN}

Kesimpulan dari penelitian ini adalah Pendidikan dan Pelatihan yang diselenggarakan Pusdiklatwas BPKP di Bogor, maupun di Perwakilan BPKP di kota lainnya, berdasarkan indikator yang dipakai dalam penelitian ini yakni: materi yang diajarkan, metode yang digunakan, sarana fasilitas pendukung, kemampuan Widyaiswara (WI)/ Instruktur dan kemampuan peserta diklat, berada pada kategori tinggi/baik sampai sedang/cukup baik. Kompetensi auditor berdasarkan indikator yang dipakai dalam penelitian ini: Kognitif (Pengetahuan), Psikomotorik (Keterampilan), Attitude/ Behavioral (Sikap/ Perilaku), Motivation (Motivasi), Responsibility (Tanggung Jawab) secara umum berada kategori tinggi. Pendidikan dan pelatihan (diklat) memiliki pengaruh positif dan signifikan terhadap peningkatan kompetensi auditor.

* Corresponding author's e-mail: ekhatyo11@gmail.com

http://openjournal.unpam.ac.id/index.php/JIA 
Jurnal Ilmiah Akuntansi Universitas Pamulang - Vol. 7, No. 2, Juli 2019 - Marito \& Prasetya

\section{DAFTAR PUSTAKA}

Amelia, G. (2007). Analisis Pengaruh Pendidikan dan Pelatihan Internal Terhadap Pembelajaran Pegawai (Studi Kasus BAKOSURTANAL Cibinong-Bogor). Skripsi pada Fakultas Ekonomi dan Manajemen, Institut Pertanian Bogor, Bogor.

Arep,I dan H.Tanjung. (2002). Manajemen Sumber Daya Manusia. Universitas Trisakti, Jakarta.

Badan Pengawasan Keuangan dan Pembangunan. (1996). Himpunan Peraturan Jabatan Fungsional Auditor dan Angka Kreditnya Di Lingkungan Aparat Pengawasan Fungsional Pemerintah. BPKP, Jakarta.

Cahayani,A. (2005). Strategi dan Kebijakan Manajemen Sumber Daya Manusia, PT.Indeks, Jakarta.

Dessler,G. (1997). Manajemen Sumber Daya Manusia.PT.Prenhallindo,Jakarta.

Hasibuan,M.S.P. (2003). Manajemen Sumber Daya Manusia. Bumi Aksara, Jakarta.

Imam Ghozali (2001). Aplikasi Analisis Multivariate Dengan Program SPSS, Badan Penerbit Universitas Diponegoro, Semarang. (2002). Statistik Non Parametrik-Teori dan Aplikasi Dengan Program SPSS, Badan Penerbit Universitas Diponegoro, Semarang.

Mangkunegara, A.P. (2002). Sumber Daya Manusia Perusahaan. PT.Remaja Rosdakarya, Bandung.

Mangkuprawira,Tb,S. (2004). Manajemen Sumber Daya Manusia Strategik. Ghalia Indonesia, Jakarta.

Nawari. (2010). Analisis Regresi Dengan SPSS 1977. Penerbit PT Elex Media Komputindo, Jakarta.

Nasir, M. (2005). Metode Penelitian. Ghalia Indo nesia, Bogor.

Peraturan Pemerintah Nomor 192 Tahun 2014 Tentang Badan Pengawasan Keuangan dan Pembangunan.

Purbayu Budi Santosa dan Ashari. (2005). Analisis Statistik Dengan Microsoft Excel \& SPSS, Penerbit Andi, Yogyakarta.

Setiawan,M. (2006). Analisis Program Pelatihan dan Pengaruhnya Terhadap Kinerja Karyawan (Studi Kasus PT.Mitra Infoparama).

Simamora, H. (2004). Manajemen Sumber Daya Manusia. STIE YKPN, Yogyakarta.

Sugiyono. (2009). Metodologi Penelitian Bisnis. Alfabeta, Bandung.

Umar, H. (2005). Riset Sumber Daya Manusia dalam Organisasi, PT.Gramedia Pustaka Utama, Jakarta. 